Digital

Biomarkers

Sponsored by:

evidation

\section{The Future of Digital Health}

Guest Editor

leuan Clay, San Mateo, CA

28 figures, 27 in color, and 21 tables, 2020 


\section{Sponsor Note}

This Supplement Issue was sponsored by Evidation Health, with the concept and content brought together by their Head of Digital Measures Ieuan Clay. All articles went through our standard peerreview process and were edited by Editor-in-Chief Ray Dorsey and Assistant Editor-in-Chief Adam Cohen.

\section{Conflict of Interest Statement Guest Editors}

I.C. was previously an employee of Novartis and is currently an employee of, and holds stock options in, Evidation Health. He has received payment for lecturing on Digital Health at the ETH Zurich and FHNW Muttenz. He is an Editorial Board member at Karger Digital Biomarkers and a founding member of the Digital Medicine Society.

\author{
S. Karger \\ Medical and Scientific Publishers \\ Basel $\cdot$ Freiburg $\cdot$ Hartford $\cdot$ Oxford \\ Bangkok $\cdot$ Dubai $\cdot$ Kuala Lumpur . \\ Melbourne $\cdot$ Mexico City . \\ Moscow $\cdot$ New Delhi $\cdot$ Paris . \\ Shanghai $\cdot$ Tokyo \\ www.karger.com
}

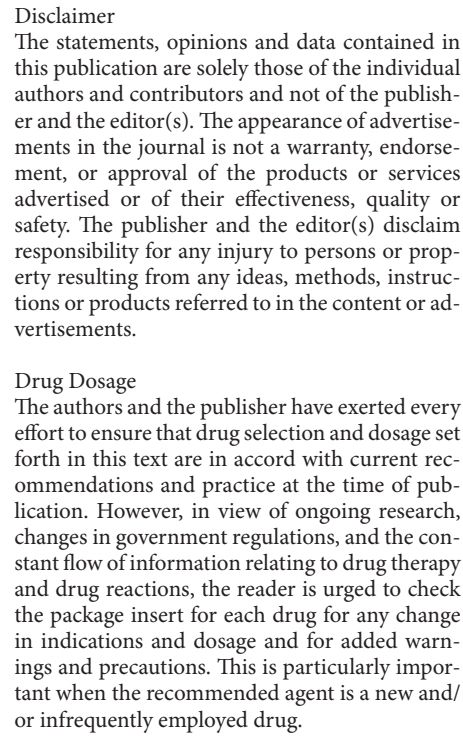

The statements, opinions and data contained in this publication are solely those of the individual authors and contributors and not of the publisher and the editor(s). The appearance of advertisements in the journal is not a warranty, endorsement, or approval of the products or services advertised or of their effectiveness, quality o safety. The publisher and the editor(s) disclaim responsibility for any injury to persons or property resulting from any ideas, methods, instruc tions or products referred to in the content or advertisements.

Drug Dosage

The authors and the publisher have exerted ever effort to ensure that drug selection and dosage set forth in this text are in accord with current rec ommendations and practice at the time of publication. However, in view of ongoing research, changes in government regulations, and the constant flow of information relating to drug therapy and drug reactions, the reader is urged to check the package insert for each drug for any change in indications and dosage and for added warnings and precautions. This is particularly important when the recommended agent is a new and/ or infrequently employed drug.

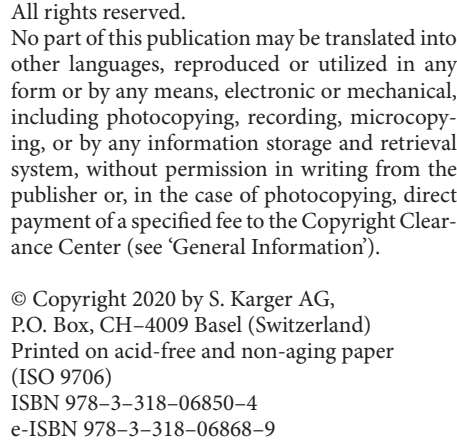

No part of this publication may be translated into other languages, reproduced or utilized in any form or by any means, electronic or mechanical including photocopying, recording, microcopying, or by any information storage and retrieval system, without permission in writing from the publisher or, in the case of photocopying, direct payment of a specified fee to the Copyright Clearance Center (see 'General Information').

(c) Copyright 2020 by S. Karger AG, P.O. Box, CH-4009 Basel (Switzerland) Printed on acid-free and non-aging paper (ISO 9706)

ISBN 978-3-318-06850-4

e-ISBN 978-3-318-06868-9 


\section{Contents}

1 Editorial

Clay, I. (San Mateo, CA)

Viewpoint - Maturation

3 The Path Forward for Digital Measures: Suppressing the Desire to Compare Apples and Pineapples

Houts, C.R. (Chapel Hill, NC); Patrick-Lake, B.; Clay, I. (San Mateo, CA); Wirth, R.J. (Chapel Hill, NC)

13 A Roadmap to Inform Development, Validation and Approval of Digital Mobility Outcomes: The Mobilise-D Approach

Rochester, L. (Newcastle upon Tyne); Mazzà, C. (Sheffield); Mueller, A (Basel); Caulfield, B.; McCarthy, M. (Dublin); Becker, C. (Stuttgart); Miller, R. (Basel); Piraino, P. (Berlin); Viceconti, M. (Bologna); Dartee, W.P. (Basel); Garcia-Aymerich, J. (Barcelona/Madrid); Aydemir, A.A. (Darmstadt); Vereijken, B. (Trondheim); Arnera, V. (Geneva); Ammour, N. (Chilly-Mazarin); Jackson, M. (London); Hache, T.; Roubenoff, R. (Basel); on behalf of the Mobilise-D Consortium

Maturation

28 Precompetitive Consensus Building to Facilitate Use of Digital Health Technologies to Support Parkinson Disease Drug Development through Regulatory Science

Stephenson, D. (Tucson, AZ); Alexander, R. (Cambridge, MA); Aggarwal, V. (Tucson, AZ); Badawy, R. (Birmingham); Bain, L. (Philadelphia, PA); Bhatnagar, R. (Tucson, AZ); Bloem, B.R. (Nijmegen); Boroojerdi, B. (Brussels); Burton, J. (Tucson, AZ); Cedarbaum, J.M. (Tucson, AZ/ Woodbridge, CT); Cosman, J. (Cambridge, MA/Chicago, IL); Dexter, D.T. (London); Dockendorf, M. (Kenilworth, NJ); Dorsey, E.R. (Rochester, NY); Dowling, A.V. (Cambridge, MA); Evers, L.J.W. (Nijmegen); Fisher, K. (Cambridge, MA); Frasier, M. (New York, NY); Garcia-Gancedo, L. (Stevenage); Goldsack, J.C. (Boston, MA); Hill, D.; Hitchcock, J.

(Tucson, AZ); Hu, M.T. (Oxford); Lawton, M.P. (Tucson, AZ); Lee, S.J. (Kenilworth, NJ); Lindemann, M. (Basel); Marek, K. (New Haven, CT); Mehrotra, N. (Kenilworth, NJ); Meinders, M.J. (Nijmegen); Minchik, M. (Tucson, AZ); Oliva, L. (Cambridge, MA); Romero, K. (Tucson, AZ); Roussos, G. (Tucson, AZ/London); Rubens, R. (Cambridge, MA); Sadar, S.; Scheeren, J. (Tucson, AZ); Sengoku, E. (Brussels); Simuni, T. (Evanston, IL); Stebbins, G. (Chicago, IL); Taylor, K.I. (Basel); Yang, B. (Copenhagen); Zach, N. (Cambridge, MA); on behalf of the Critical Path for Parkinson's Consortium

50 Robust Step Detection from Different Waist-Worn Sensor Positions: Implications for Clinical Studies

Tietsch, M. (Basel/Nürnberg); Muaremi, A. (Basel); Clay, I. (San Mateo, CA); Kluge, F. (Nürnberg); Hoefling, H. (Basel); Ullrich, M.; Küderle, A.; Eskofier, B.M. (Nürnberg); Müller, A. (Basel) 
59 Assessment of Fatigue Using Wearable Sensors: A Pilot Study

Luo, H.; Lee, P.-A. (Basel); Clay, I. (San Mateo, CA); Jaggi, M. (Lausanne); De Luca, V. (Basel)

73 Predicting Subjective Recovery from Lower Limb Surgery Using Consumer Wearables

Karas, M. (San Mateo, CA/Baltimore, MD); Marinsek, N.

(San Mateo, CA); Goldhahn, J. (Zurich); Foschini, L.; Ramirez, E.; Clay, I. (San Mateo, CA)

87 "It's Not as Simple as Just Looking at One Chart": A Qualitative Study Exploring Clinician's Opinions on Various Visualisation Strategies to Represent Longitudinal Actigraphy Data

Keogh, A.; Johnston, W.; Ashton, M.; Sett, N.; Mullan, R.; Donnelly, S. (Dublin); Dorn, J.F.; Calvo, F. (Basel); Mac Namee, B.; Caulfield, B. (Dublin)

100 The Collaborative Aging Research Using Technology Initiative: An Open, Sharable, Technology-Agnostic Platform for the Research Community

Beattie, Z.; Miller, L.M. (Portland, OR); Almirola, C. (Miami, FL); $\mathrm{Au}$-Yeung, W.-T.M.; Bernard, H.; Cosgrove, K.E.; Dodge, H.H. (Portland, OR); Gamboa, C.J. (Chicago, IL); Golonka, O.; Gothard, S.; Harbison, S.; Irish, S.; Kornfeld, J.; Lee, J.; Marcoe, J.; Mattek, N.C.; Quinn, C.; Reynolds, C.; Riley, T.; Rodrigues, N.; Sharma, N.; Siqueland, M.A. (Portland, OR); Thomas, N.W. (Ottawa, ON); Truty, T. (Chicago, IL); Wall, R.; Wild, K.; Wu, C.-Y. (Portland, OR); Karlawish, J. (Philadelphia, PA); Silverberg, N.B. (Bethesda, MD); Barnes, L.L. (Chicago, IL); Czaja, S. (Miami, FL/New York, NY); Silbert, L.C.; Kaye, J. (Portland, OR)

Next Generation

119 The Role of Digital Navigators in Promoting Clinical Care and Technology Integration into Practice

Wisniewski, H. (Boston, MA); Gorrindo, T. (Washington, DC); Rauseo-Ricupero, N. (Boston, MA); Hilty, D. (Mather, CA); Torous, J. (Boston, MA)

136 Defining and Developing the Workforce Needed for Success in the Digital Era of Medicine

Goldsack, J.C. (Boston, MA); Zanetti, C.A. (Parker, CO) 